J. Clin. Chem. Clin. Biochem.

Vol. 20, 1982, pp. 509-514

\title{
Validity of Monoamine Oxidase in Serum for Diagnosis of Liver Cirrhosis: Estimation of Predictive Values, Sensitivities and Specificities
}

\section{By A. M. Gressner}

Department of Clinical Chemistry and Pathobiochemistry of the Medical Faculty of the Technical University (RWTH), Aachen, FRG

\section{P. Roebruck}

Department of Medical Statistics and Documentation, RWTH, Aachen and

\section{W. Tittor}

Stoffivechselklinik der LVA Württemberg, Division of Hepatology and Metabolic Diseases, Bad Mergentheim

(Received October 26, 1981/January 28, 1982)

Summary: The validity of monoamine oxidase (EC 1.4.3.4) activity in serum for the diagnosis of fibroproliferative liver disorders was assessed by measuring the specificity, sensitivity and positive and negative predictive values of the enzyme. Enzyme activity was measured in sera of 567 patients including those with biochemically and/or histologically verified non-fibrotic liver diseases $(n=64)$, liver fibrosis $(n=45)$, and liver cirrhosis $(n=51)$.

The fraction of liver cirrhotic subjects with pathologically elevated monoamine oxidase activity $(>630 \mathrm{U} / \mathrm{l})$ was 0.61 , whereas only 0.16 of the cases with liver fibrosis and 0.11 of those with non-fibrotic liver diseases had abnormally high enzyme activities. Among the various categories of diseases tested, significantly increased enzyme activities were confined to liver cirrhosis and chronic active hepatitis. For liver cirrhosis, sensitivities and specificities were calculated as functions of various cut-off (critical) values of monoamine oxidase activity in serum, and with respect to a reference population of healthy men and non-cirrhotic subjects. The predictive value of the positive test result (enzyme activity higher than $720 \mathrm{U} / 1$ ) at a prevalence of liver cirrhosis of maximum 0.033 (estimated incidence of chronic liver diseases in West-Germany) is 0.68 if tested against healthy persons and less than 0.30 if tested against patients with non-liver cirrhotic diseases. It is concluded that monoamine oxidase is probably not helpful in the early diagnosis of fibroproliferative liver dysfunctions but may provide a parameter of complications of cirrhosis, e.g. portal-systemic collateral circulation (portal hypertension).

\section{Die Zuverlässigkeit der Monoamin-Oxidase im Serum für die Diagnose der Lebercirrhose: Bestimmung der Vorhersagewerte, Sensitivitäten und Spezifitäten}

Zusammenfassung: Die Kriterien der diagnoștischen Zuverlässigkeit wie Spezifität, Sensitivität sowie positive und negative prädiktive Werte der Monoamin-Oxidase (EC 1.4.3.4) Aktivität im Serum für fibroproliferative Lebererkrankungen wurden berechnet. Enzymaktivitäten wurden bestimmt in den Sera von 567 Patienten einschließlich derer mit biochemisch und/oder histologisch verifizierten nicht-fibrotischen Lebererkrankungen $(n=64)$, Leberfibrose $(n=45)$ und Lebercirrhose $(n=51)$. Es wird festgestellt, daß ein Anteil von 0,61 der cirrhotischen Patienten pathologisch erhöhte Monoamin-Oxidase Aktivitäten $(>630 \mathrm{U} / 1)$ besitzt, wohingegen nur 0,16 der Fälle mit Leberfibrose und 0,11 derjenigen mit nicht-fibrotischen Lebererkrankungen abnormal hohe Enzymaktivitäten aufweisen. Unter den verschiedenen, getesteten Krankheitskategorien sind deutlich erhöhte Enzymaktivitäten auf die Fälle mit Lebercirrhose und chronisch aktiver Hepatitis beschränkt. Für Lebercirrhosen wurden Sensitivitäten und Spezifitäten berechnet in Abhängigkeit verschiedener kritischer Werte der Monoamin-Oxidase Aktivität im Serum und in Bezug auf Referenzpopulationen von gesunden Erwachsenen sowie nicht-cirrhotischen Patienten. Der Vorhersagewert des positiven Testergebnisses (Enzymaktivität höher als $720 \mathrm{U} / 1$ ) bei einer Prävalenz der Lebercirrhosen von maximal 0,033 (geschätzte Inzidenz der chronischen Lebererkrankungen in der Bundesrepublik Deutschland) beträgt 0,68, wenn berechnet in Bezug auf gesunde Personen und weniger als 0,30, wenn berechnet in Bezug auf nicht-lebercirrhotische Patienten. Aus den Ergebnissen ist zu schließen, daß die Monoamin-Oxidase wahrscheinlich nicht hilfreich ist in der Frühdiagnose fibroproliferativer Lebererkrankungen, sondern möglicherweise ein Parameter für Komplikationen der Lebercirrhose, z. B. der porto-systemischen Kollateralzirkulation (portale Hypertension) darstellt. 


\section{Introduction}

In the past 20 years incidence and mortality of liver cirrhosis have nearly doubled and still continue to increase in most countries mainly due to an increase in the number of etiologic factors such as alcohol consumption, infections with hepatotropic viruses and chronic intake of facultative hepatotoxic drugs $(1-4)$. It is estimated that currently more than 300000 patients per year die because of the direct or indirect consequences of liver cirrhosis (5). Both the large number of patients having chronic liver damage (roughly two millions in WestGermany, (6)) and the chronicity of the disease result in a considerable social and economic significance of this group of diseases (7-9).

In the sequence of pathobiochemical alterations in longterm damaged liver parenchyma cirrhosis represents the final, mostly irreversible stage (10-12). Thus, any successful handling of the disease is confined to early phases, in which it may be possible to stop excessive intercellular connective tissue formation. This, however, necessitates the availability of valid, organ- and disease-specific, sensitive diagnostic parameters of active fibroplasia. Specimen collection must also be convenient for the patient so that it can be performed frequently during the follow-up of chronic liver damage. As reviewed previously $(12,13)$ the measurement of monoamine oxidase (EC 1.4.3.4) in serum has been suggested as a valuable diagnostic procedure for liver fibrosis and cirrhosis because elevated activities were found to be frequently associated with this disease. However, up to now there have been no quantitative assessments of the diagnostic validity of serum monoamine oxidase for liver cirrhosis, i.e. the calculation of predictive value (14), and diagnostic sensitivity and specificity (15) are lacking. Using the modified (16) colorimetric assay for monoamine oxidase in serum (17) we determined the activity of this enzyme in sera of patients with histologically verified liver diseases and non-liver diseases in order to calculate the criteria of diagnostic validity mentioned above.

\section{Materials and Methods}

\section{Materials}

The commercial sources of the materials used for determination of the activity of monoamine oxidase in serum and of the quality control sera were as reported previously (16).

\section{Specimen collection}

During a period of 8 months sera of 567 patients and 243 apparently healthy persons (16) were analysed for activity of monoamine oxidase. The patients with no clinical symptoms and no laboratory test results typical for liver diseases, were assigned to one of the categories listed in figure 1 . On the basis of pathologic liver function tests and the results of histologic examination of liver biopsy specimens patients with liver diseases were subdivided into those with acute viral hepatitis $B$, chronic persistent hepatitis, chronic active hepatitis, liver fibrosis and liver cirrhosis, respectively. With the exception of most of the patients suffering from chronic liver diseases, the analysed sera were those received routinely at the central laboratory of the department of clinical chemistry of the Technical University, Aachen. Sera of patients having chronic liver diseases $(n=105)$ were obtained mainly from the Stoff wechselklinik der LVA, Bad Mergentheim. Since the activity of monoamine oxidase in serum decreases rather rapidly during storage at room temperature (16) enzyme activity was assayed either immediately after blood collection or, as in the case of sera obtained from the Stoffwechselklinik, catalytic function was preserved by deepfreezing the specimens for 5 to 8 days.

Venous blood was taken in the morning, allowed to clot for about $1 \mathrm{~h}$ at room temperature and serum was prepared by centrifugation using Sure-Sep II serum-plasma separator.

Assay of monoamine oxidase (EC 1.4.3.4)

In principle the activity of the enzyme was determined according to the colorimetric procedure of Ono et al. (17) including slight modifications as described recently (16). The criteria of analytical validity of the assay procedure have been reported in a previous communication (16). Inter assay precision was determined with Validate A (Gödecke) and Ortho Normal (Ortho Diagnostics) as control sera and found to have a $\mathrm{CV}$ between 10 and $14 \%$.

\section{Statistical evaluation}

In calculating the criteria of the diagnostic validity of serum monoamine oxidase for liver cirrhosis, against the respective reference population of healthy persons or non-cirrhotic patients, the following definitions (15) were used:

\section{a) diagnostic sensitivity}

Proportion of pathologic monoamine oxidase activities within the liver-cirrhotic population

\section{b) diagnostic specificity}

Proportion of normal monoamine oxidase activities within the reference population

c) predictive value of pathologic monoamine oxidase activity (positive test result)

Probability of the presence of liver cirrhosis if the test result is positive; with respect to the reference population.

d) predictive value of normal monoamine oxidase activity (negative test result)

Probability of the absence of cirrhosis if the test result is negative; with respect to the reference population.

The predictive values are functions of the prevalence defined as prevalence cirrhosis = proportion of cirrhotic cases within the total population under consideration.

The estimates of the criteria defined above were calculated by the relative frequencies of positive and negative test results in the given samples for various cut-off (critical) values (upper "normal" limit) of monoamine oxidase activity. Enzyme activities above these limits were regarded as pathologic.

\section{Results}

\section{Monoamine oxidase activity in sera of patients with various liver and non-liver disorders}

In a previous study the reference ranges for the activity of serum monoamine oxidase were determined and: found to have an upper limit ( $+2 \mathrm{~s}$ value) of $630 \mathrm{U} / \mathrm{1}$ (16). An overall impression of the distribution of monoamine oxidase activities in sera of patients with a variety of non-liver and liver diseases is given by figure 1. Except for diabetes mellitus monoamine oxidase activity is quite independent of the type of disease, i.e. the mean activity in the categories tested was in the range between 


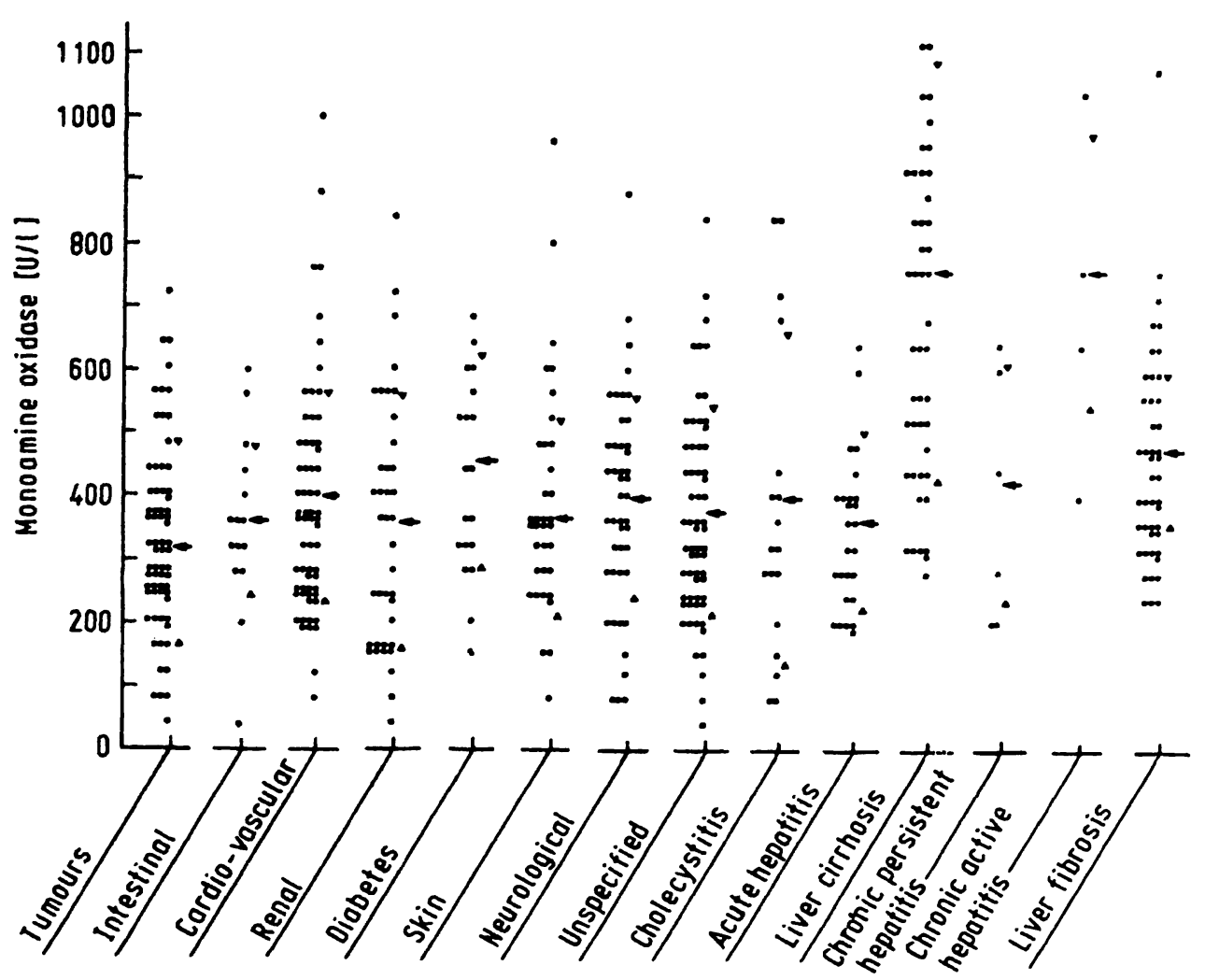

Fig. 1. Frequency distribution of monoamine oxidase activities measured in the sera of patients with neoplastic ( $n=68$, tumours), gastro-intestinal $(n=15$, intestinal), cardio-vascular $(n=63$, card.-vascular), renal $(n=40)$, dermatological $(n=35$, skin) and neurological $(n=45$, neurol.) disorders and in patients with diabetes mellitus $(n=19)$ and various entities of diseases $(n=63$, unspecified); chronic persistent hepatitis $(n=6)$, chronic active hepatitis $(n=4)$, cholecystitis $(n=18)$, acutc hepatitis $(n=26)$, liver cirrhosis $(n=51)$, liver fibrosis $(n=45) ; \leftarrow$ indicates the mean activity in each category. $\nabla$ the upper $1 \mathrm{~s}$ limit, $\triangle$ the lower $1 \mathrm{~s}$ limit.

300 and $400 \mathrm{U} / 1$. Diabetic patients have a slightly elevated mean enzyme activity of $450 \mathrm{U} / 1$. Among persons suffering from acute and chronic liver diseases only those with cirrhosis or chronic active hepatitis have elevated enzyme activities. The mean activity in sera of patients with cirrhosis and active hepatitis was found to be $770 \mathrm{U} / 1$; extreme values were above $1100 \mathrm{U} / 1$ (fig. 1). In accordance with previous reports $(18-21)$ acute viral hepatitis is not associated with pathologically high monoamine oxidase activities $(>630 \mathrm{U} / 1)$ in sera. Thus, significently increased enzyme activities are confined to patients with liver cirrhosis and chronic active hepatitis, but the number of tested patients with the latter disease is rather low. This is confirmed by the data showing the frequency distribution of serum monoamine oxidase activities in cirrhotic subjects in comparison to those with liver fibrosis, non-fibrotic liver diseases and nonliver diseases (tab. 1). Whereas the fraction of liver cirrhotic subjects with pathologically elevated serum monoamine oxidase activity $(>630 \mathrm{U} / 1)$ is 0.61 , only 0.16 of the cases with liver fibrosis and 0.11 of those with non-fibrotic liver diseases are associated with elevated enzyme activities. Among the persons with non-liver diseases 0.07 have monoamine oxidase activities higher than $630 \mathrm{U} / 1$. It is noteworthy that monoamine oxidase activities in sera of cirrhotic subjects seem to have a bimodal frequency distribution (see also fig. 1).

Tab. 1. Frequency distribution of monoamine oxidase activities in sera of healthy persons and patients with liver fibrosis, cirrhosis, non-fibrotic liver diseases; and non-liver diseases, respectively.

\begin{tabular}{|c|c|c|c|c|c|c|c|c|c|c|}
\hline \multirow[t]{2}{*}{ Category } & & \multicolumn{9}{|c|}{ Monoamine oxidase, cataly tic activity (U/1) } \\
\hline & & $\begin{array}{l}0- \\
510\end{array}$ & $\begin{array}{l}511- \\
540\end{array}$ & $\begin{array}{l}541- \\
570\end{array}$ & $\begin{array}{l}571- \\
600\end{array}$ & $\begin{array}{l}601- \\
630\end{array}$ & $\begin{array}{l}631- \\
660\end{array}$ & $\begin{array}{l}661- \\
690\end{array}$ & $\begin{array}{l}691- \\
720\end{array}$ & $\geqslant 721$ \\
\hline $\begin{array}{l}\text { Healthy persons } \\
\text { Non-liver diseases } \\
\text { Non-fibrotic liver diseases } \\
\text { Liver fibrosis } \\
\text { Liver cirrhosis }\end{array}$ & $\begin{array}{l}(n=243) \\
(n=407) \\
(n=64) \\
(n=45) \\
(n=51)\end{array}$ & $\begin{array}{r}209 \\
330 \\
51 \\
31 \\
14\end{array}$ & $\begin{array}{r}17 \\
1.4 \\
2 \\
1 \\
3\end{array}$ & $\begin{array}{r}5 \\
20 \\
0 \\
2 \\
3\end{array}$ & $\begin{array}{l}2 \\
9 \\
1 \\
3 \\
0\end{array}$ & $\begin{array}{l}3 \\
6 \\
3 \\
1 \\
0\end{array}$ & $\begin{array}{l}3 \\
9 \\
1 \\
2 \\
3\end{array}$ & $\begin{array}{l}1 \\
3 \\
0 \\
2 \\
0\end{array}$ & $\begin{array}{l}1 \\
6 \\
1 \\
0 \\
1\end{array}$ & $\begin{array}{r}2 \\
10 \\
5 \\
3 \\
27\end{array}$ \\
\hline
\end{tabular}




\section{Sensitivity and specificity of monoamine oxidase for liver cirrhosis}

Since liver cirrhosis was the only disease-category having an abnormal distribution of monoamine oxidase activity in serum, its sensitivity and specificity for cirrhosis were estimated as function of various cut-off values (upper "normal" limit of monoamine oxidase activity) (fig. 2). It is evident that the specificity of monoamine oxidase for the detection of liver cirrhosis related to a population of healthy persons (fig. 2a) and to non-liver cirrhotic patients (fig. 2b), respectively, improves with increasing cut-off values. Of course, this is accompanied by a loss of sensitivity (fig. 2). The specificity of monoamine oxidase for cirrhosis is slightly higher with respect to a reference population of healthy men than with respect to non-cirrhotic patients suffering from a variety of other liver and non-liver diseases (fig. 2a, b).

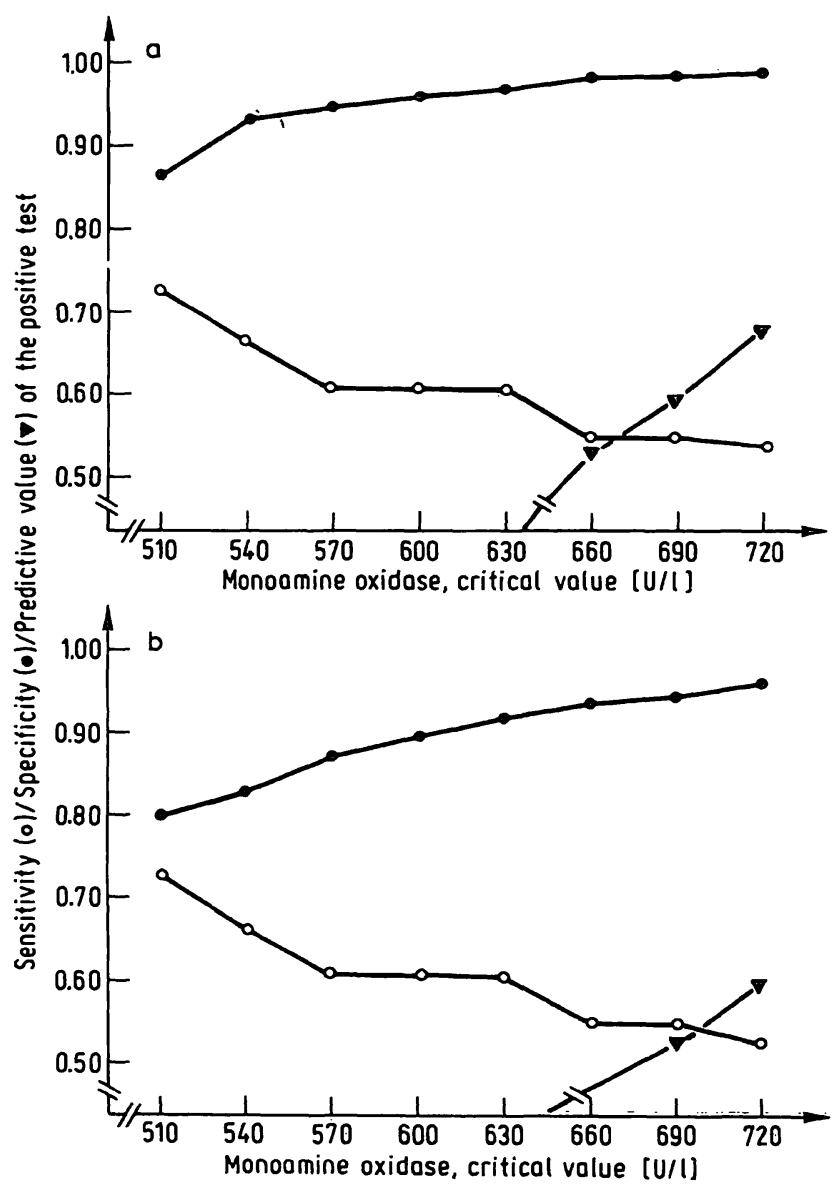

Fig. 2. Estimated sensitivity $(0)$ and specificity $(\bullet)$ of monoamine oxidase for liver cirrhosis as function of various cut-off (critical) values of activity (above which the test result is regarded as pathologic). In figure $2 a$ the criteria are tested against a population of healthy persons, in figure $2 \mathrm{~b}$ against patients suffering from a variety of liver and non-liver diseases.

The predictive values of the positive test as a function of cut-off values at a prevalence of cirrhosis of 0.033 (estimated prevalence of chronic liver diseases in West-Germany) (6) with respect to healthy persons (fig. $2 a, \longmapsto$ ) and 0.09 (fraction of cirrhotic patients in our test sample) with respect to non-cirrhotic patients (fig. $2 \mathrm{~b}, \longmapsto$ ) are illustrated.

The predictive value in figure $2 \mathrm{~b}$ would further decrease if based on a prevalence of 0.033 as in fig. 2 a (compare fig. 4).

\section{Predictive values of monoamine oxidase for liver cirrhosis}

The estimated predictive values of the positive (abnormal high monoamine oxidase activity) and negative (normal monoamine oxidase activity) test result, as a function of the prevalence of cirrhosis, are illustrated in figures 3 and 4. As shown, the predictive values of monoamine oxidase are better at a cut-off value of $720 \mathrm{U} / 1$ than at $630 \mathrm{U} / 1$ (fig. 2) and against a reference population of healthy persons (fig. 3) than against diseased persons (fig. 4). If we assume a prevalence of chronic liver diseases including liver cirrhosis of 0:033 in West-Germany (6) monoamine oxidase activities above $720 \mathrm{U} / 1$ would have a predictive value of 0.68 if tested against healthy persons and of less than 0.30 if tested against patients suffering from diseases other than liver cirrhosis.

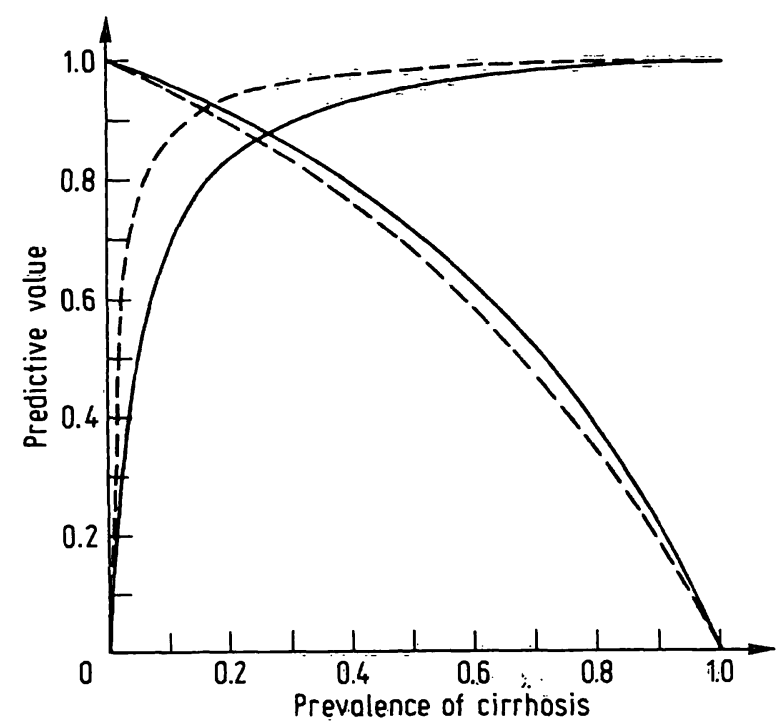

Fig. 3. Estimated predictive values of normal (negative test result, ) and pathologically elevated (positive test result, /) monoamine oxidase activities as a function of disease prevalence with respect to a healthy population. They were calculated for a cut-off value of enzyme activity of $630 \mathrm{U} / 1(-)$ and $720 \mathrm{U} / 1\left({ }_{--}\right)$, respectively.

\section{Discussion}

Previous studies have established elevated activities of serum monoamine oxidase under a variety of pathological conditions, in particular in progressive liver fibrosis (17-24). The latter observation pointed to a possible diagnostic significance of this parameter for fibroproliferative liver disorders although a functional role of this enzyme in hepatic connective tissue metabolism, e.g. in collagen and/or elastin cross-linking is not firmly established $(19,21,23)$. In addition, purified amine oxidase and liver lysyl oxidase, the enzyme catalyzing the initial steps of collagen and elastin cross-link formation (25), were found to be antigenically different, and, thus; , structurally not identical (26). Although resembling the 
type B mitochondrial outer membrane monoamine oxidase (27-29) several criteria, in particular the sensitivity to the action of lathyrogens $(30,31)$, indicate clearly marked differences between serum monoamine oxidase and the tissue type of amine oxidase. Whatever the functional role and the origin of circulating monoamine oxidase, our data confirm on a quantitative basis the potential but limited diagnostic utility of this enzyme. In contrast to some earlier reports $(23,24)$ significantly elevated activities were found nearly exclusively in fully developed liver cirrhosis but not in liver fibrosis. Indeed, the frequency distribution of enzyme activities in sera of patients with liver fibrosis and non-liver diseases shows no significant differences. Thus, estimation of monoamine oxidase is not helpful in the diagnosis of early stages of fibroproliferative liver dysfunctions, in which fibrostatic therapy might be successful. In addition to this observation the U-shaped frequency distribution of monoamine oxidase activities in sera of cirrhotic patients (table 1) suggests that stimulated hepatic connective tissue synthesis and/or

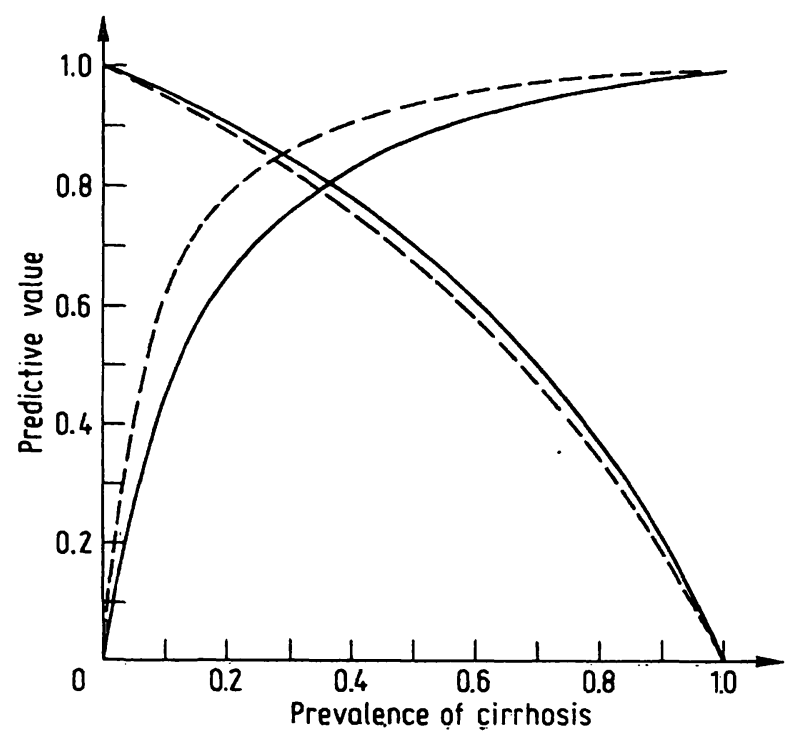

Fig. 4. Predictive values of normal (negative result, ) ) and pathologically elevated (positive test result, $\nearrow$ ) monoamine oxidase activities as a function of disease prevalence with respect to non-liver cirrhotic patients (cutoff value of $630 \mathrm{U} / 1, \ldots$; cut-off value of $720 \mathrm{U} / 1$, $---)$.

\section{References}

1. Hahn, E. G., Ott, U. \& Martini, G. A. (1980) Z. Gastroenterólogie $18,453-469$.

2. Jorke, D. \& Reinhardt, M. (1977) Acta Hepato-Gaștroenterol. 24, 220-225.

3. de Lint, J. (1981) J. Stud. Alcohol 42, 48-56.

4. Bode, J. Ch. (1979) Kassenarzt 19, 1031-1038.

5. Martini, G. A. \& Bode, Ch. (1970) Internist 11, 84-93.

6. Hagen, J. (1981) Therapiewoche 31, 3300-3309.

7. Hoppe, R. (1980) Leber Magen Darm 10, 163-166.

8. Kulpe, W. (1979) Klinikarzt 8, 265-268.

9. Popper, H., Davidson, Ch. S., Leevy, C. M. \& Schaffner, F. (1969) New Engl. J. Med. 281, 1455-1458.

10. Popper, H. \& Udenfriend, S. (1970) Amer. J. Med. 49, 707-721. increased concentration of intercellular matrix proteins can not be the sole (if any) determinant of raised serum monoamine oxidase activity. Instead, elevated enzyme activity might indicate a common complication of advanced fibrotic distortion of the liver parenchyma, i.e. increased hepatic sinusoidal pressure (portal hypertension) and portal-systemic collateral circulation (22). In fact, a striking positive correlation has been found between serum monoamine oxidase activity and intrahepatic venous pressure (22), but not with other, routinely applied liver function tests $(21,22)$. If this assumption is valid the record of enzyme activity could be valuable in the follow-up of known cirrhosis rather than in its early diagnosis and, thus, might have prognostic significance. The rather low diagnostic sensitivity, specificity (fig. 2) and predictive values (figs. 3 and 4) of abnormally high monoamine oxidase in serum at an assumed prevalence of cirrhosis of 0.001 or less are in favour of this view. The criteria might be improved in more selected populations with greater prevalence of cirrhosis and/or by consideration of additional diagnostic parameters in a multivariate framework. Pathobiochemically, the differentiation of the various isoenzymes of serum monoamine oxidase in liver-cirrhotic subjects $(23,32,33)$ might contribute to an improvement of the diagnostic validity of the test. Special care has to be taken on the marked instability of the enzyme in vitro (16), which otherwise might influence negatively the diagnostic validity of this parameter. Further studies have to show whether the estimation of serum monoamine oxidase in conjunction with other proposed parameters of stimulated hepatic connective tissue metabolism (13) is advantageous for an early diagnosis of fibroproliferative liver disorders. This goal, however, will be difficult to reach at present because of the largely unknown pathogenesis of liver fibrosis and cirrhosis, the chronicity of the process, and the ubiquitous distribution of the connective tissue elements in the body (34).

\section{Acknowledgment}

We gratefully acknowledge the expert technical assistance of Mrs. Elke Stecklum and the help of Mr. H.-P. Ambos.

11. Rojkind, M. \& Dunn, M. A. (1979) Gastroenterology 76, 849-863.

12. Gressner, A. M. (1980) Med. Welt 31, 11-16.

13. Gressner, A. M. (1979) Lab. med. 3, 201-208.

14. Vecchio, Th. J. (1966) New Engl. J. Med. 274, 1171-1173.

15. Büttner, J. (1977) J. Clin. Chem. Clin. Biochem. 15, 1-12.

16. Gressner, A. M. (1980) J. Clin. Chem. Clin. Biochem. 18, 921-927.

17. Ono, T., Eto, K., Sakata, Y. \& Takeda, M. (1975) J. Lab. Clin. Med. 85, 1022-1031.

18. Nilsson, S. E., Tryding, N. \& Tufvesson, G. (1968) Acta Med. Scand. 184, 105-108.

19. Ito, K., Nakagawa, J., Minakuchi, C. \& Fukase, M. (1971) Digestion 4, 49-58. 
20. Kirchner, J. P. \& Castell, D. O. (1972) Gastroenterology 62, 771.

21. Kirchner, J. P., Nebel, O. T. \& Castell, D. O. (1974) Mil. Med. 139, 952-954.

22. McEwen, C. M. \& Castell, D. O. (1976) J. Lab. Clin. Med. $70,36-47$.

23. Malin, A. W. S., Davis, L. M. \& Castell, D. O. (1976) Proc. Soc. Exp. Biol. Med. 151, 40-43.

24. Nakano, H., Yamamoto, Y., Ohnishi, S., Ito, K. \& Imura, H. (1978) Clin. Chim. Acta 88, 315-319.

25. Pinnell, S. R. \& Martin, G. R. (1968) Proc. Natl. Acad. Sci. USA $61,708-714$.

26. Yasunobu, K. T., Ishizaki, H. \& Minamiura, N. (1976) Mol. Cell. Biochem. 13, 3-29.

27. Neff, N. H. \& Yang, H. Y. T. (1974) Life Sci. 14, 20612074.
28. Murphy, D. L. (1978) Biochem. Pharmacol. 27, 18891893.

29. Cáwthon, R. M. \& Breakefield, X. O. (1979) Nature 281, $692-694$.

30. Page, R. G. \& Benditt, E. P. (1967) Proc. Soc. Exp. Biol. Med. 124, 454-459.

31. De Marco, C., Coletta, M. \& Bombardieri, G. (1965) Nature $205,176$.

32. Malin, A. W. S. \& Castell, D. O. (1974) Biochem. Med. 9, 373-385.

33. Malin, A. W. S. \& Castell, D. O. (1975) Biochem. Med. 13, $141-156$

34. Gressner, A. M. (1982) Current Topics Clin. Chemistry, in press.

Prof. Dr. A. M. Gressner

Abt. für Klinische Chemie und Pathobiochemie Klinisch-Chemisches Zentrallaboratorium der Med. Fakultät der RWTH Aachen Goethestr. 27-29

D-5100 Aachen 